症例

インターフェロン治療後 8 年目に診断された肝細胞癌の 1 例

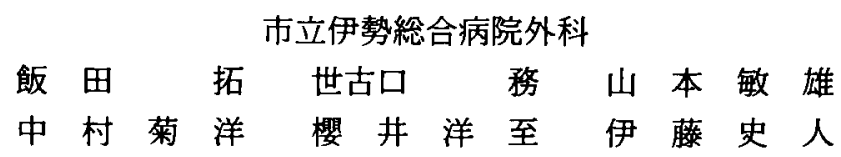

症例は69歳男性. 1992年 C 型慢性肝炎に対しインターフェロン (IFN) 治療を施行さ れ、トランスアミナーゼは持続正常化，血中 HCV-RNA も持続陰性化し，著効した。治 療前後の肝組織像も新犬山分類 F 3 A 2 から F 2 A 1 に改善した. 1995年までの画像検查 では異常を認めず，以後患者の自己判断にて診察が中断されていた。 2000 年著効 8 年後 肺気腫にて他院通院中, 軽度の肝機能障害を指摘. 各種検查にて肝右葉の $12 \mathrm{~cm}$ 大の肝細 胞癌と診断され，肝右葉切除術を施行した。組織学的には中分化型肝細胞癌で，併存肝 病変はF 1 A 0 であり, 相対的非治瘾切除であった。IFN 治療著効後肝細胞癌本邦報告例 を検討すると, 約半数が治療後 3 年以内に肝癌が診断され，また肝線維化の高度な症例 ほど短期間に肝癌が発現していた．画像検査で発見不可能な前癌病変や微小癌が存在す ることがあり，IFN 治療著効例でも肝癌発現に留意し，継続的な定期䛦察が必要と考え られた。

㮂引用語：インターフェロン治療, 肝細胞癌, C 型慢性肝炎

緒 言

C 型慢性肝炎は長期経過を経て,肝硬変に進行し,肝 紐胞癌を高率に合併する疾患であり，C型慢性肝炎に 対するインターフェロン（以下 IFN）治療はウイルス を排除し，肝組織像の改善が期待できる唯一の治療法 である゙．IFN著効例においては肝組織像の改善とと もにに肝癌発生率が有意に低下する゙かか，最近 IFN 著 効例での肝細胞癌症例の報告も散見される，今回われ われはIFN 治療著効、年後に診断されたり 人肝細胞 癌の 1 切除例を経験したので報告する.

$$
\text { 症例 }
$$

患者：69藏，男性。

主訴：特になし。

家族歴：特記事項なし。

既往歴：26歳時肺結核にて左肺上葉切除術を施行さ

れ，その際翰血歷あり。

飲酒歴：機会飲酒程度.

現病歴：平成 2 年 4 月他院にて肝機能異常と $\mathrm{HCV}$

2001 年 2 月 13 日受付 2001 年 4 月18日採用

〈所属施設住所〉

テ5160014 伊婑市楠部町3038
抗体陽性 (genotype II) を指摘された。平成 4 年 4 月 肝生検を施行され，組織学的には新犬山分類 F 3 A 2 の慢性活動性肝炎と診断された（図 1 a). 平成 4 年 5 月12日より IFN $\alpha 2$ b (イントロンの) を1000万単位 2 週間連日投与, その後は週 3 回で12週間の継続投与が 行われた，投与開始 4 週後にはGOT, GPT とも正常 化し, 平成 4 年 7 月には HCV-RNAの陰性が確認さ れた。平成 4 年11月の肝生検では炎症性細胞浸潤は軽 度となり，F2A1に改善した（図 1 b)）そその後平成 て年11月まではトランスアミナーゼは持続正常化, HCV-RNA U持絸陰性化し著効となった。外来通院

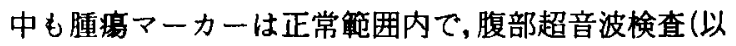
下腹部 US) でも異常は認めなかったが, 平成 7 年11月 以後は患者の自己判断により診察が中断されていた。 平成 12 年 3 月他院で肺気腫治療中, 血液生化学検查て 肝機能異常を指摘され，腹部 US で肝右葉に腫瘤を認 め, 判查加療目的で平成12年 4 月17日当科紹介入院と なった。

入院時現症：身長 $167 \mathrm{~cm}$ ，体重67kg. 結膜に貧血， 黄疸なし．腹部は平坦，軟で圧痛を認めず，肝を右鎖 骨中線上 3 横指触知した。

入院時検査成籍：血1设一般検査は異常なく，肝機能 


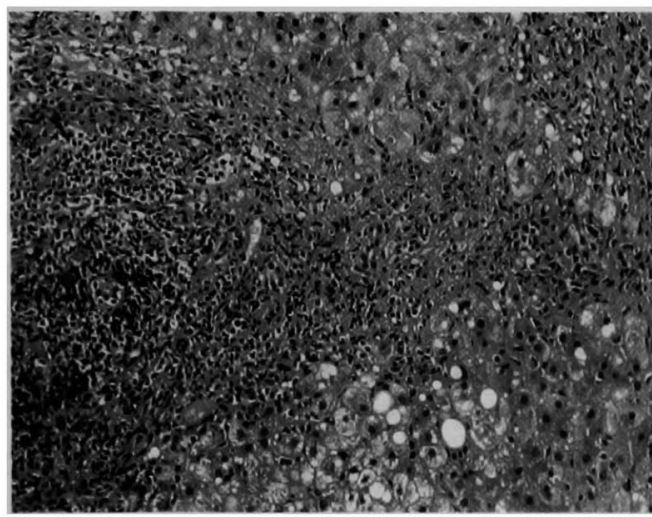

a

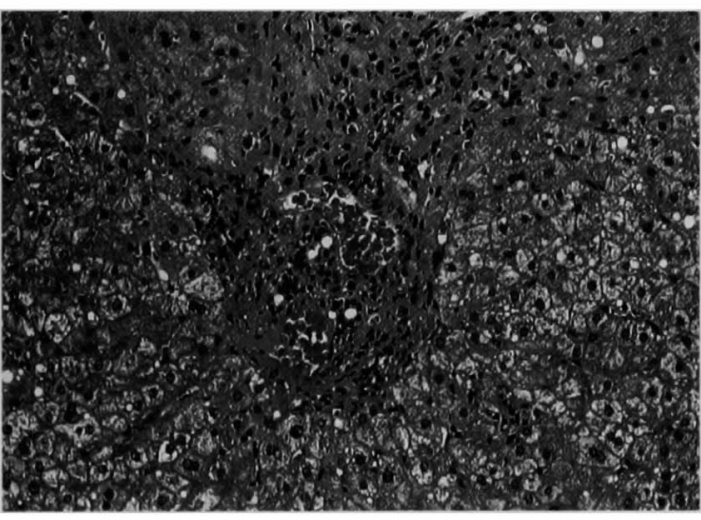

b

図 1 a 肝生検組織像 (IFN 治療前, 平成 4 年 4 月)：新犬山分類 F 3 A 2 の慢性活動性肝炎像が見られた (H E. $\cdot 20)$.

b 䀒生検組織像 (IFN 治療後, 平成 4 年11月)：グリソン鞘軽度拡大も, 細胞浸潤は軽度となり, F 2 A 1 に改善した（H. E. 20)。

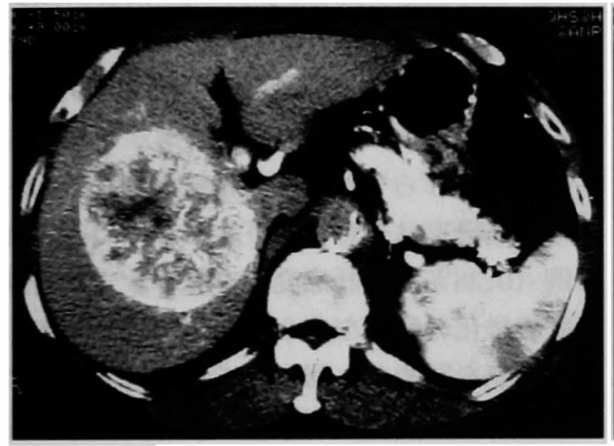

a

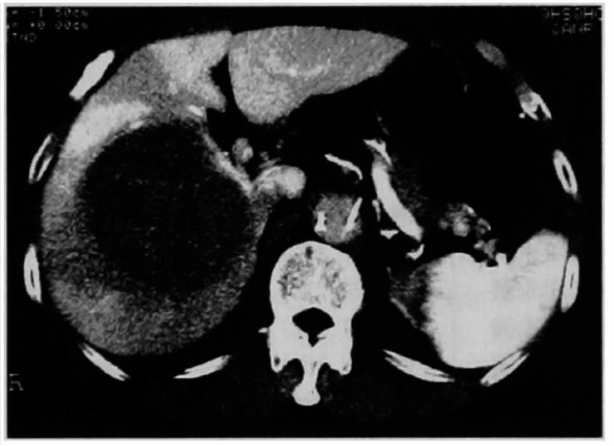

b

図 2 a CT-A：訮右葉に早期より辺縁から不整濃染する腫瘍を認めた。

b CT-AP：同腫瘍は門脈相では境界明瞕な低吸収域として描出された。

検査では GOT 51IU/L, GPT 49IU/L とトランスアミ ナーゼの軽度上昇を認め, ヒアルロン酸 $97 \mathrm{ng} / \mathrm{ml}$, $\mathrm{ICGR}_{15}$ は2 $4.5 \%$ と高値を示した。呼吸機能検査で著明 な閉塞性呼吸障害を認めた。腫瘍マーカーは AFP 2590ng/ml, PIVKA-II 11500mAU/ml と共に異常高 値を示した. PCR 法による血中 HCV-RNA, HBs 抗 原, HBs 抗体いずれも陰性であった。

腹部 US : 肝右葉全体を占める約 $12 \mathrm{~cm}$ 大の内部不 均一な腫瘍性病変を認めた。

CT：CT-A では肝右葉に早期より辺縁から不整に 濃染する $12 \mathrm{~cm}$ 大の腫瘍を認め(図 2 a ), CT-AP では 同腫瘍は境界明瞭な低吸収域として描出された（図 2 b).

腹部血管撮影検査：右葉に巨大な腫瘍濃染像を認め
たが，左右門脈枝への浸潤は認めなかった。

以上より肝右葉の単発性巨大肝細胞癌と診断, 平成 12 年 5 月 16 日肝在葉切除術を施行した。

病理組織学的所見：腫瘍径は $10 \times 12 \mathrm{~cm}$ で組織学的 には中分化型肝細胞癌（図 3 a ）で, eg, fc (-), fc$\inf (-), \operatorname{sf}(+), \mathrm{s} 0, \mathrm{vp} 1, \mathrm{vv} 0, \mathrm{~b} 0, \operatorname{im} 0, \mathrm{p} 0$, 2 1, tw (+), T 3 N 0 M 0 Stage III で, 相対的非治隐 切除であった。非腫瘍部は肝硬変, 活動型肝炎の所見 なく線維化も軽度で新犬山分類 F $1 \mathrm{~A} 0$ と診断された (図 3 b).

術後経過は良好で, 術後17日目に退院. 腫瘍マーカ 一も低下したが, 術後 5 力月のC゙「にて残肝に $1 \sim 2$ $\mathrm{cm}$ 大の 3 個の腫瘍再発が疑われており, 今後化学療 法およびPEITの予定である。 


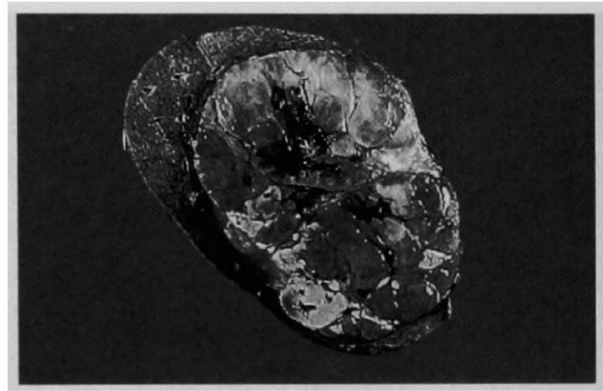

a

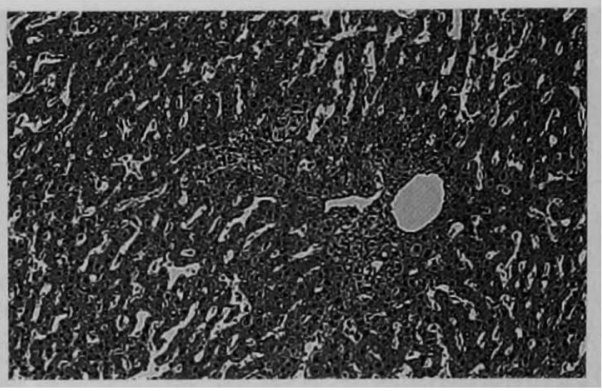

b

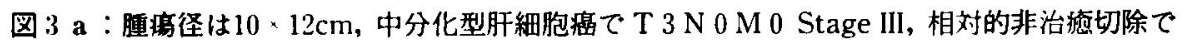
あった。

b：非腫鹪部は肝硬変なく，線維化が著明であり，F１Ａ０ と診断された（H.E. × 20）。

表 1 IFN 著勃後肝細盷䚀本邦報告27例の臨床病理学的 検討

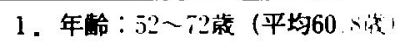

2. 性別：男性24例, 女性 3 例

3. 発癌個数：筆発性25例，多発性 2 例

4. 肝細胞蕾診断時期と腫的径

\begin{tabular}{|c|c|c|}
\hline 猃断時期 & 症例数 & 平均腫㾁径 \\
\hline IFN終了後 1 年末蓝 & 6 例 $\left(22.2^{\circ} a\right)$ & 平均 $2.8 \mathrm{~cm}$ \\
\hline $1 \sim 2$ if & 8 例 $\left(29.6^{\circ}{ }_{0}\right)$ & $2.0 \mathrm{~cm}$ \\
\hline $2 \sim 3$ 年末满 & 2 例 $\left(7.4^{\circ} \circ\right)$ & $3.0 \mathrm{~cm}$ \\
\hline $3 \sim 4$ 年末满 & 6 例 $\left(22.20_{0}^{0}\right)$ & $3.9 \mathrm{~cm}$ \\
\hline $\sim 5$ 年末渾 & 3 例 $(11.1 \%)$ & $5.4 \mathrm{~cm}$ \\
\hline $5 \sim 6$ 年末満 & 1 利 $\left(3.7^{\circ} \%\right)$ & $6.0 \mathrm{~cm}$ \\
\hline 6 年以上 & 1 例 $\left(3.7^{\circ}\right)$ & $12.0 \mathrm{~cm}$ \\
\hline
\end{tabular}

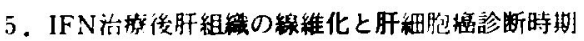

\begin{tabular}{|c|c|c|}
\hline & 应例数 & 診断時期 \\
\hline $\mathrm{F}+$ & 5 例 & IFN終了後 $11.2 \pm 12.3$ 力月 \\
\hline F 3 & 3 例 & $18.3 \pm 15.3$ 力月 \\
\hline $\mathrm{F} 2$ & 5 例 & $52.2 \pm 11.5$ 力月 \\
\hline F 1 & 3 例 & $61.3 \pm 31.1$ 力月 \\
\hline $\mathrm{Fo}$ & 1 例 & 12 月 \\
\hline 記载なし & 10 例 & \\
\hline
\end{tabular}

6. 治撩诘 外科的切除 21 例

TAE 4 例 記戟机し 2例

7. 予後

無再発生存例 9 例 $(3 \sim 81$ 力月)

再発例 5 利( 壮了さ.0力月で再発。 内 2 (列は再切除施行。)

\section{考察}

1986年 Hoofnagle ら”が(型慢性肝炎に対する IFN 治療を報告して以米, IF N 治療はトランクアミナ
一ゼひ正常化, ウイルスの排除, 肝組織像の改善に有 効て，肝癌発生抑制効果が明らかにされている2)4. 本 邦でも1992年より IFN 治療の保険診療が承認され, 以 後C型慢性肝炎に対しIFN 治療が施行され, 約 $30 \sim 40 \%$ 症例はトランスアミナーゼの正常化，血中 HCV-RNA の持続陰性化 (以下著効) するとされてい る.

Yoshida ら"は IFN 未治療例と比較し, IFN 著効例 での発癌率は有意に低下するものの, 著効例789例中10 例 $(0.38 \%)$ に肝癌発現を認め，また著効例で，かつ 肝線維化の軽度な F $0 / 1$ 症例で257例中 1 例 (0.11\%) の発楾を認めたと報告しており，著効例においても肝 癌発現には注意在要する。

IFN治療著效例での肝癌発現の実数は少なくない と思われるが、1995年以後詳細の明らかな IFN 治療著 効後肝細胞癌本邦報告は26(例) 24)で，自験例を加えた 27例についてその臨床病理学的特徵を検討した（表 1 ).

年路は 52〜 72歳で，平均60.8歳であった，男女比は 男性24例，女性 3 例で，発癌個数は单発性25例，多発 性 2 例であった。肝細胞澏診断時期を見てみると IFN 治療後 1 年末満が 6 例 $(22.2 \%) ， 1 \sim 2$ 年末満が 8 例 $\left(29.6{ }^{\prime \prime}\right) ， 2 \sim 3$ 年末満が 2 例 $(7.4 \%)$ と 3 年末満 での発必恬例が27例中 16 例 $\left(59.3^{\circ} \%\right)$ と半数以上を占 めた。さりに 3 年〜 5 年が 9 例 $(33.3 \%)$ で， 5 年以 降での診断症例は自験例を含め，2 例 $(7.4 \%)$ のみで あった。腄瘍径は診断時期が遅くなるほど増大し, こ の理由としては IFN 治療後の follow up が 3 年を超 えると不定期になり肝徱晾断が遅れることが考えられ た.IFN 治療後肝組䄉の線維化と肝癌診断時期につい て詳細が明らかな17例を検討すると,F 45 例, F 33 
例, F 25 例, F 13 例, F 01 例であり, 肝癌診断時 期はF十ではIFN治療後11.2土12.3力月, F 3 て

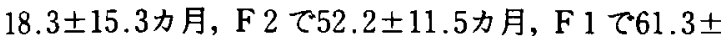
31.1 月, F 0 で12力月と肝線維化が軽度な症例ほど, IFN 治療終了から肝癌診断までの時期は長期であっ た. 治療法は外科的切除が 21 例, TAEが 4 例で, 約 80 \%の应例で外科的切除が選択されていた，その理由と しては, IFN 治療が著効し, ICGR 15 などの肝予備力が 比較的良好に保たれていた点，また多くが単発性肝細 胞癌であり，肝硬変を背景とする場合しばしば見られ る多中心性発癌が認められなかった点などが挙げられ る.予後について記載の明らかな14例についてみると， 無再発生存 9 例は, $3 \sim 81$ 力月無再発生存中であった. 再発例は自釦例を含め 5 例で，5２0力月（平均 12.0 力月）で再発を来し，内 2 例は再切除が施行されてい た.

肝癌発現時期について，本邦報告例の約 6 割の症例 が IFN 治療終了後 3 年末澫に発癌している点からも， IFN 治療が著効し, $\mathrm{HCV}^{-を}$ を排除しても, 肝病変が進行 した状態では各種画像唡査で発見することができない 前癌病変や馓小肝細胞癌が存在している可能性があ る.腫瘍発育速度について, 笠原ら ${ }^{23}$ は肝細胞癌が直径 $5 \mathrm{~mm}$ の癌結節になるまでに15年〜20年， $5 \mathrm{~mm}$ から

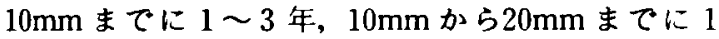
〜 2 年を要するとし, doubling time は腫瘍悪性度に もよるが腫愓径が $15 \mathrm{~mm}$ を超えると発育速度は急速に 速くなる24と報告されている. IFN 治療前からの微小 癌の存在も否定できないが, IF N 治療後に発癌したと 思われる報告例 ${ }^{251}$ あり, 自験例の腫瘍径が $12 \mathrm{~cm}$ と 巨大であること考虑すると，その両方の可能性が考 えられた。

IFN 治療の長期予後が報告されつつあるが，自験例 の如く治療著効後も肝細胞癌発現例も存在し，肝線維 化の高度な症例ほど肝癌発現に注意を要し，長期にわ たる継続的な定期骖察が必要と考えられた。

$$
\text { 結語 }
$$

IFN 治療著効 8 年後に診断された巨大肝紐胞癌の 1 切除例を経験した。併存肝病変に前癌病変, 微小肝 細胞癌が存在することがあり，IFN 治撩著効例でも肝 癌発現に留意し，長期の継続的な定期診察か必要と考 えられた。

\section{文献}

1) Kasahara A, Hayashi N, Hiramitu N, et al: Ability of prolonged interferon treatment to suppress relapse after cessation of therapy in multicenter randomized controlled trial. Hepatology $21: 291-297,1995$

2）横須賀収, 細田和彦, 小俣政男他：C 型慢性肝炎の インターフェロン療法の組織学的長期予後. 日臨 $7: 1841-1846,1994$

3) Hoofnagle $\mathrm{JH}$, Mullen $\mathrm{KD}$, Jones $\mathrm{DB}$, et al : Treatment of chronic non- $A$, non- $B$ hepatitis with recombinant human alpha interferon. $\mathrm{N}$ Engl J Med 315 : 1575-1578, 1986

4) Yoshida H, Yasui S, Moriyama M, et al : Interferon Therapy Reduce the Risk for Hepatocellular Carcinoma: National Surveillance Program of Cirrhotic and Noncirrhotic Patients with Chronic Hepatitis $\mathrm{C}$ in Japan. Ann Int Ned $131: 174^{-\cdots} 181,1999$

5）岡村圭也, 山崎 克, 大村卓味他：インターフェ ロン治療著奻後 5 年目に診断された肝細胞癌切除 の1列. 肝腈 $41: 43-47,2010$

6）池田美和, 木野山真拈，新山聚一他：IFN 治療著 効後に肝細胞癌を合併したし 型慢性肝炎の 1 例. 肝缄 $36: 485-490,1995$

7) Tamori A. Kuroki T, Nishiguchi S, et al : Case of small hepatocellular carcinoma in the caudate lobe detected after interferon caused disappearance of hepatitis $C$ virus. HepatoGastroenterology $43: 1079--1083,1996$

8) Hirashima N, Mizokami M, Orito E, et al: Development of hepatocellular carcinoma in a patient with chronic hepatitis $\mathrm{C}$ infection after a complete and sustained response to interferon a. J Gastroenterol Hepatol 11:1079-1083, 1996

9) Sugiura N, Sakai Y, Ebara M, et al : Detection of hepatocellular carcinoma after interferon therapy for chronic hepatitis C : clinical study of 26 cases. J Gastroenterol Hepatol 11 : 535539,1996

10）蒔田富士雄, 齐藤修一, 松本達彦他：インターフ エロン療法観祭期間に出現・切除された肝細胞癌 症例の検討。日消病会誌 $93 ： 406-410 ， 1996$

11）榎村尚之，小笠原誠，土肥 䒚他：IFN 治療著効 後, 経過中に肝細胞癌を合併したじ型慢性肝炎の 1 例. 日内会誌 $86 ： 1961-196 \% 3,1997$

12）玉井 微, 関 寿人, 入口隆一他：(型慢性肝炎に 対するインターフェロン療法が著効を示したにも 拘わらず 4 年 + カ後に朋細胞癌の存在が確認さ れた 1 例. 朋堿 $39: 750-755,1998$

13）柴田 実, 山本雅 - , 小野塚靖他：インターフェ 
ロン療法著効後に肝発癌を認めたC 型慢性肝炎

の 1 例. 医と薬学 $39: 505-507,1998$

14）大岡真也，田中正彦，村上武司他：インターフェ ロンが著効し投与終了後 2 年で肝癌の発生をみた C 型慢性肝炎の 1 例. 医と蒋学 $39: 508-510$, 1998

15）星野裕治，泉 並木，清水まゆみ他：インターフ エロン治療後 1 年で肝発瘦し手術治療した 1 例。 医と薬学 $39: 511-515,1998$

16）畠山修司，佐藤芳之，池田有成他：インターフェ ロン著効後 3 年の経過で肝細胞癌を合併したC 型慢性肝炎の1例。医と薬学 $39: 516--519,1998$

17）江㚼 明, 末浦克明, 神山传典他：インターフェ ロン療法が著劫したが，1年 5 カ月後肝癌が発見

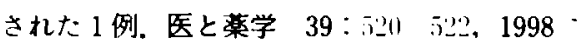

18）富上義憲，新井淳也，手島一陽他：インターフェ ロン療法が著効?した後肝細胞㾇を発症したC 型慢性肝炎の 1 例. 医と薬学 $39: 523-527,1998$

19）斎藤 聡，小林 瑞，小朴䜣宏他：インターフェ ロン著効後に発癌したC 型慢性肝疾患症例の娭 討. 医と薬学 $39: 528-532,1998$
20) Yamaguchi K, Omagari $K$, Kinoshita $H$, et al : Development of hepatocellular carcinoma in a patient with chronic hepatitis $\mathrm{C}$ after 6 years of a sustained and complete response to INF- $\alpha$. J Clin Gastroenterol 29:207-209, 1999

21）宮尾直樹, 芹澤 宏, 熊谷直樹他：インターフェ ロン治療著効後約三年で肝細胞癌が認められたC 型慢性肝炎の 1 例. 日消病会誌 $96: 535-539$, 1999

22）須鄉広之，北山尚也，岩田豊二地：IFN 治療著効 後に肝細胞癌を合併したC 型慢性肝炎の 1 例. 肝 胴 $41: 195-198 ， 2000$

23）笠原彰紀，林 紀夫：C 型肝炎と肝細胞癌一臨床 的見地から。肝・胆 - 脺 $37: 205-213,1998$

24）江原正明, 吉川正治, 杉浦信之他：肝細胞癌の早 期発見と画像診断. Medicina 29:1626-1629, 1992

25）泉 並木, 柴田 実, 上司裕史他：C 型慢性肝炎1 ンターフェロン治療による完全著効後の肝発癌. 医と薬学 $39: 533-537,1998$

\title{
A CASE OF GIANT HEPATOCELLULAR CARCINOMA DIAGNOSED 8 YEARS AFTER INTERFERON THERAPY
}

\author{
Taku IIDA, Tsutomu SEKOGUCHI, Toshio YAMAMOTO, \\ Kikuhiro NAKAMURA, Hiroyuki SAKURAI and Fumito ITO \\ Department of Surgery, Municipal Ise General Hospital
}

A 69-year-old man was pointed out slight impairment of liver function while he was treated for pulmonary emphysema at another hospital, and was referred to the hospital in 2000. Eight years before admission, in 1992, he had received interferon (IFN) therapy for chronic hepatitis $\mathrm{C}$, with an excellent result : transaminases were continuously normalized and blood $\mathrm{HCV}$-RNA showed lasting negative conversion; and histology of liver tissue was improved to F2A1 after the therapy from F3A2 before the therapy according to the new Inuyama's classification. Thereafter the patient had not been followed by his own decision. After admission, hepatocellular carcinoma $12 \mathrm{~cm}$ in size in the right lobe was diagnosed and a right lobectomy of the liver was made. Histologically, it was moderately differentiated hepatocellular carcinoma, with a concomitant hepatic lesion of F1A0. A relatively non-curative resection was made.

In a review of domestic cases in which excellent results with INF therapy followed by hepatocellular carcinoma, about half of them were diagnosed as hepatic carcinoma within 3 years after INF therapy. And cases revealing severer hepatic fibrosis had earlier occurrence of hepatic carcinoma. There remains a possibility that precancerous lesions or minute cancer which are impossible to be detected by imaging procedures exist after successful IF $N$ therapy, so that periodic follow-up examinations would be required for such cases by paying consideration to the occurrence of hepatic carcinoma. 